\title{
Evidence of a seamount effect on aggregating visitors
}

\author{
Telmo Morato ${ }^{1,2, *}$, Divya Alice Varkey ${ }^{2}$, Carla Damaso $^{1}$, Miguel Machete $^{1}$, \\ Marco Santos ${ }^{1}$, Rui Prieto ${ }^{1}$, Ricardo S. Santos ${ }^{1}$, Tony J. Pitcher ${ }^{2}$ \\ ${ }^{1}$ Departamento de Oceanografia e Pescas, Universidade dos Açores, 9901-862, Horta, Portugal \\ ${ }^{2}$ Fisheries Centre, Aquatic Ecosystems Research Laboratory, 2202 Main Mall, University of British Columbia, Vancouver, \\ British Columbia V6T 1Z4, Canada
}

\begin{abstract}
It has been suggested that seamounts hold higher abundances of some 'visiting' animals, such as tuna, sharks, billfishes, marine mammals, sea-turtles and even seabirds, but this has been based on sparse records, and warrants further examination. In this paper we use data from a fishery observer program to examine whether the predicted higher abundances of tuna, marine mammals, sea turtles and seabirds actually occur around Azores seamounts and to map the distribution of the various species. Our results indicate that some marine predators (skipjack Katsuwonus pelamis and bigeye tuna Thunnus obesus, common dolphin Delphinus delphis and Cory's shearwater Calonectris diomedea borealis) were significantly more abundant in the vicinity of some shallowwater seamount summits. Our methodology, however, failed to demonstrate a seamount association for bottlenose dolphins Tursiops truncatus, spotted dolphin Stenella frontalis, sperm whale Physeter macrocephalus, terns Sterna hirundo and S. dougalli, yellow-legged gull Larus cachinnans atlantis and loggerhead sea turtles Caretta caretta. Seamounts may act as feeding stations for some of these visitors. Not all seamounts, however, seemed to be equally important for these associations. Only seamounts shallower than $400 \mathrm{~m}$ depth showed significant aggregation effects. These seamounts may be considered hotspots of marine life in the Azores, and a special effort should be made in order to ensure a sustainable management of these habitats.
\end{abstract}

KEY WORDS: Seamounts $\cdot$ Tuna $\cdot$ Seabirds $\cdot$ Marine mammals $\cdot$ Sea turtles $\cdot$ Association $\cdot$ Azores

\section{INTRODUCTION}

Seamounts have been recently recognized as highly important for fisheries, biodiversity and conservation as they support often isolated but rich underwater ecosystems (Pitcher et al. 2007). One important characteristic of seamounts is that they tend to accelerate water currents (Genin et al. 1986, Boehlert 1988), thus enhancing the flux of prey organisms flowing over them (Tseytlin 1985, Genin et al. 1986, Koslow 1997). This characteristic has been used to explain the occurrence of large aggregations of bottom fishes around seamounts.

While the importance of seamounts for bottom fishes is very well documented (Boehlert \& Sasaki 1988, Koslow 1997, Morato et al. 2006), their importance to visiting pelagic organisms has been poorly examined. It has been hypothesised (see below) that there are higher abundances of some 'visiting' animals (such as tuna, sharks, billfishes, marine mammals, sea turtles and even seabirds) over seamounts, but this has been based on sparse records and warrants further examination.

It is known from fishers' observations and from tagging studies that some seamounts host populations of bigeye tuna Thunnus obesus (Holland et al. 1999, Itano \& Holland 2000, Sibert et al. 2000, 2003, Musyl et al. 2003), yellowfin tuna T. albacares (Holland et al. 1999, Itano \& Holland 2000, Sibert et al. 2000, Klimley et al. 2003, 2005), albacore T. alalunga (Yasui 1986) and skipjack Katsuwonus pelamis (Fonteneau 1991). There are few studies that have investigated whether these populations consist of resident animals or transient visitors. Regardless of whether individuals are resident or transient, the increased abundances of tuna associated with seamounts has caused fishing fleets to focus 
on seamounts to increase their yields (Yasui 1986, Fonteneau 1991, Adam et al. 2003). Other pelagic fishes such as billfishes (Ward et al. 2000, Sedberry \& Loefer 2001, Klimley et al. 2005) and pelagic sharks (Hazin et al. 1998, Klimley et al. 1988, 2005) also appear to be attracted to complex, high-relief bottom structures, where high fishing pressure may cause them to be subject to local depletion. The reasons for these aggregations are still under debate, but most seamounts probably act both as feeding stations and as orientation points in larger-scale movement patterns (e.g. Holland et al. 1999, Fréon \& Dagorn 2000).

Although several works have correlated cetacean occurrence with complex and steep topographies (e.g. Balcomb 1989, Schoenherr 1991, Cañadas et al. 2002, Hooker et al. 2002, Hastie et al. 2004, Yen et al. 2004), the literature addressing their association with seamounts is scarce (Gregr \& Trites 2001, Waring et al. 2001). For sea turtles, Santos et al. (2007) concluded that seamounts are 'hotspots' for loggerhead Caretta caretta because they find that tracked sea turtles moved toward seamounts, where they have increased residence time. For seabirds, Cory's shearwater Calonectris diomedea, yellow-legged gull Larus cachinnans atlantis, Madeiran storm petrel Oceanodroma castro (Monteiro et al. 1996), Cassin's auklet Ptychoramphus aleuticus (Yen et al. 2004, 2005) and black-footed albatross Diomedea nigripes (Haney et al. 1995) have also been observed above seamount summits, where they feed on zooplankton, small fish and small cephalopods.

In the present paper, we used the seamounts mapped by Morato et al. (2008, this volume) and data from a fishery observer program to quantitatively investigate whether the abundances of tuna, marine mammals, sea turtles and seabirds observed at Azores seamounts are greater than in adjacent waters devoid of seamounts.

\section{MATERIALS AND METHODS}

Study area. The Azores archipelago is a group of 9 volcanic islands and many small islets around the MidAtlantic Ridge in the NE Atlantic Ocean (an irregular area within $33.5^{\circ}$ to $43^{\circ} \mathrm{N}, 21^{\circ}$ to $35.5^{\circ} \mathrm{W}$ ). Shallow seabeds $<600 \mathrm{~m}$ deep cover $<1 \%$ of the $953633 \mathrm{~km}^{2}$ of the Azorean EEZ. This reflects the narrowness of the island shelves, which supports scattered fishing grounds. This study was conducted in a small rectangular area of the Azores EEZ (36.20 $0^{\circ}$ to $40.20^{\circ} \mathrm{N}, 24.20^{\circ}$ to $32.00^{\circ} \mathrm{W}$ ), chosen because it includes most of the seamounts, because it has better bathymetry data than adjacent areas and because all the tuna fishing effort (and thus the fishery observer program) was conducted within this area.

In the present study, we used seamounts mapped and described in Morato et al. (2008). We focused on seamounts located in a specific area of the Azores (exclusive economic zone, EEZ) that contains 39 large seamount-like features (Fig. 1) with different shapes, heights and depths of summits. The seamounts included in this study are those with numbers 1, 3 to 28, 30, 31, 33 to 39 , and 50 to 52 as described in the Supplementary Material prepared by Morato et al. (2008), available at www.int-res.com/articles/suppl/m357p017_app.pdf.

Data collection: Azores Fisheries Observer Program (POPA). POPA (www.Popaobserver.org) was launched in 1998 with the main goal of gathering data on the pole-and-line tuna fisheries in order to certify these fisheries as 'dolphin safe'. The program covers about $50 \%$ of the tuna fleet of around 20 vessels and often covers $>50 \%$ of the tuna catches. The program operates with trained on-board observers who record data on fishing activities and other scientifically relevant information.

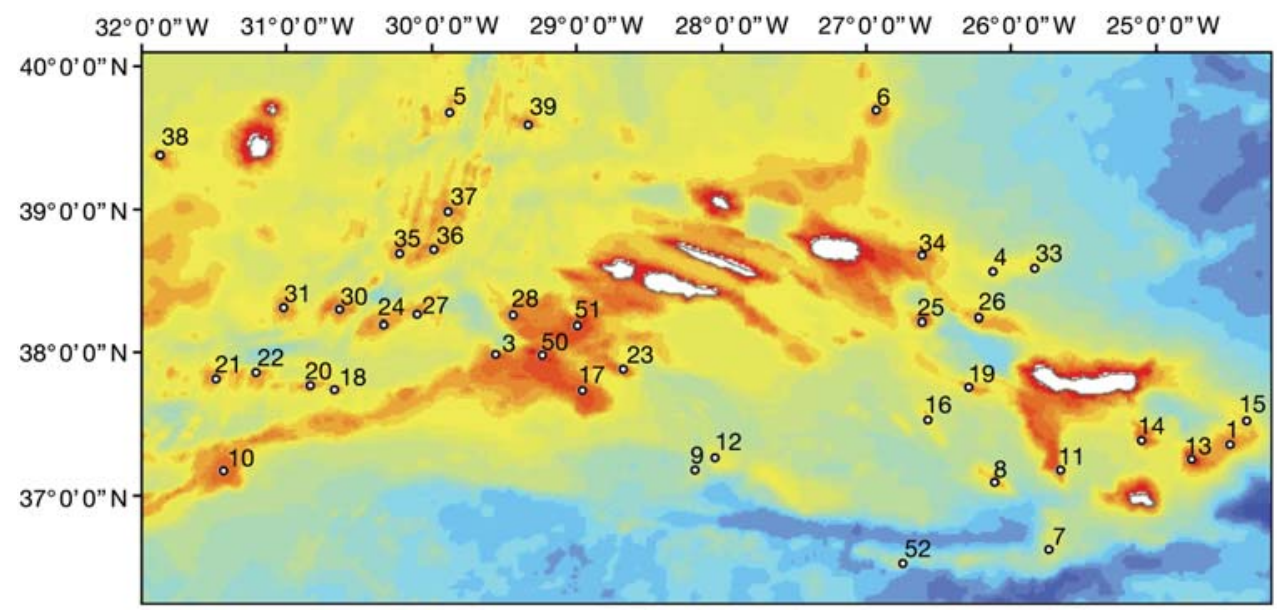

Fig. 1. The Azores archipelago and its seamounts (white circles with numbers) as described in the supplementary Material of Morato et al. (2008) available at: www.int-res.com/articles/suppl/m357p017_app.pdf. Scale goes from dark blue (deep water; about $5000 \mathrm{~m}$ ) to dark red (shallow water). Islands shown in white 
Geo-referenced data collected onboard include: fishing effort, tuna catch, sighting effort for different species and sighting of named species of marine mammals, sea turtles and seabirds. Fishing effort is estimated as the amount of time fishers spent looking for tuna schools. Sighting effort is defined as the time the observer spent searching for species other than tuna. Marine mammal, sea turtle and seabird abundances were quantified by counting individuals (or estimating when in large groups) that were within $300 \mathrm{~m}$ of the vessel. Marine mammals were often counted within $2000 \mathrm{~m}$ of the vessel. The average speed of the boats when searching was 8 knots $\left(\sim 15 \mathrm{~km} \mathrm{~h}^{-1}\right)$. Observations occurring close to island shores $(<30 \mathrm{~km})$ were excluded from the analyses because they may be biased by the 'island mass effect' (Doty \& Oguri 1956) and because we wanted to look at the effect of offshore seamounts.

Species. The present study focused on several different species of tuna, marine mammals, sea turtles and seabirds (Table 1). Tuna are thought to be present in the Azores EEZ only during summer months: our study focused on adult bigeye Thunnus obesus and skipjack Katsuwonus pelamis, the most common tuna species caught in the Azores. The first species is present during April to June, while the second is usually caught from June to October. Albacore, yellowfin and bluefin tuna T. thynnus are also caught in the Azores in small quantities. Tunas are caught with pole-and-line, usually with water spray and live bait. Only about 20 medium-sized Azorean boats (25 to $32 \mathrm{~m}$ long) fish within the EEZ and are responsible for relatively small catches (from 5000 to $10000 \mathrm{t} \mathrm{yr}^{-1}$ ).

Over 24 species of cetaceans have been reported in the Azores (Gonçalves et al. 1992, 1996, Santos et al.
1995). Of these, only a few species are regularly sighted, the most common species being the spotted dolphin Stenella frontalis, common dolphin Delphinus delphis, bottlenose dolphin Tursiops truncatus, sperm whale Physeter macrocephalus, Risso's dolphin Grampus griseus, stripped dolphin Stenella coeruleoalba and the short-finned pilot whale Globicephala macrorhynchus (Silva et al. 2003). Our study focused on only the first 4 species because of the lack of data for the others.

Five species of sea turtles occur in the Azores; however, only 3 are seen yearly (Santos et al. 1995): loggerhead Caretta caretta, leatherback Dermochelys coriacea and green turtle Chelonia mydas. Loggerhead is the most commonly sighted species. Juvenile loggerhead turtles are transported by the North Atlantic Gyre current and live a pelagic life for about $8 \mathrm{yr}$ in the eastern Atlantic, including around the Azores (Bjorndal et al. 2000). This study focused only on the loggerhead turtle.

Several seabird species are found in the Azores. However, the most commonly sighted species are Cory's shearwater Calonectris diomedea borealis, yellow-legged gull Larus cachinnans atlantis, terns Sterna hirundo and S. dougalli, Madeiran storm petrel Oceanodroma castro, greater shearwater Puffinus gravis and the little shearwater $P$. assimilis (Santos et al. 1995). The petrels feed on vertically migrating fish, while Cory's shearwater feeds often in association with marine predators such as dolphins and tuna (Monteiro et al. 1996, Clua \& Grosvalet 2001). This study focused only on Cory's shearwater, yellow-legged gull and the terns.

Data analyses. We used spatial data from the POPA program to determine whether tuna catches and sight-

Table 1. Species included in the present study, number of observations (n) by species and summary of the data on distance from observed data points to closest seamount $(\mathrm{km})$. Min.: minimum distance to seamount summit; max.: maximum distance; mean $\pm \mathrm{SD}$ : mean distance and respective $\mathrm{SD}$

\begin{tabular}{|c|c|c|c|}
\hline \multirow[t]{2}{*}{ Species } & \multirow{2}{*}{$\begin{array}{l}\text { Observations } \\
\text { (n) }\end{array}$} & \multicolumn{2}{|c|}{ Dist. to seamount $(\mathrm{km})$} \\
\hline & & Min. to Max. & Mean \pm SD \\
\hline \multicolumn{4}{|l|}{ Tuna } \\
\hline Skipjack Katsuwonus pelamis & 1675 & 0.4 to $>100$ & $50.7 \pm 49.2$ \\
\hline Bigeye tuna Thunnus obesus & 1497 & 2.0 to $>100$ & $28.4 \pm 36.3$ \\
\hline \multicolumn{4}{|l|}{ Marine mammals } \\
\hline Common dolphin Delphinus delphis & 2008 & 0.2 to $>100$ & $30.1 \pm 33.0$ \\
\hline Spotted dolphin Stenella frontalis & 528 & 0.7 to $>100$ & $44.3 \pm 53.9$ \\
\hline Bottlenose dolphins Tursiops truncatus & 303 & 0.3 to $>100$ & $29.7 \pm 33.1$ \\
\hline Sperm whale Physeter macrocephalus & 233 & 1.6 to $>100$ & $44.1 \pm 35.8$ \\
\hline \multicolumn{4}{|l|}{ Sea turtles } \\
\hline Loggerhead turtle Caretta caretta & 566 & 0.6 to $>100$ & $52.5 \pm 65.6$ \\
\hline \multicolumn{4}{|l|}{ Seabirds } \\
\hline Cory's shearwater Calonectris diomedea borealis & 1681 & 0.4 to $>100$ & $37.0 \pm 46.8$ \\
\hline Yellow-legged gull Larus cachinnans atlantis & 329 & 1.7 to $>100$ & $43.2 \pm 52.5$ \\
\hline Terns Sterna hirundo and S. dougalli & 134 & 3.2 to $>100$ & $54.2 \pm 58.9$ \\
\hline
\end{tabular}


ings of sea turtles, marine mammals and seabirds were higher closer to the seamount summits identified by Morato et al. (2008) than in other areas of the ocean. Data were available for the period from 1998 to 2004 for tuna and marine mammals and for the period from 2000 to 2004 for seabirds and sea turtles.

We built grids of tuna catch, sighting effort and sightings of different species by allocating each data point to a $0.05 \times 0.05$ degree cell $\left(\sim 5.5 \times 5.5 \mathrm{~km} \mathrm{side}^{-1}\right)$. This procedure produced 2 grids of tuna catch per $24.6 \mathrm{~km}^{2}, 1$ grid of sighting effort in hours per $24.6 \mathrm{~km}^{2}$ and several grids of numbers of individuals observed per $24.6 \mathrm{~km}^{2}$. These later grids were then divided by the effort grid to produce grids of numbers of individuals per $24.6 \mathrm{~km}^{2} \mathrm{~h}^{-1}$ search. These grids included cells with zero values, i.e. those cells with fishing or sighting effort but zero catch or observations. Null data cells were those with no fishing or sighting effort.

Distances of observation cell to nearest known seamount summit were separated into 10 classes of $10 \mathrm{~km}$ intervals from 0 to $100 \mathrm{~km}$. Each cell with data was then allocated to one of the distance classes, and the average catch and sightings were calculated for each class. The estimated averages were transformed into catches or sightings $\mathrm{km}^{-2}$.

We analysed if fishing locations were randomly selected by comparing the frequency distribution of the distances to seamount summit of the dataset of tuna fishing events and of a set of an equal number of randomly selected locations using the G-statistic for the log-likelihood ratio goodness-of-fit.

One-way analysis of variance (ANOVA) was used to test for significant differences between $\log (x+1)$ transformed mean abundances (catch or sightings) at different distances from seamount summits. When significant $F$-test values from the ANOVA were found, we looked for those means contributing to the effect using a post hoc comparison. In this case, we used Dunnett's multiple comparison test to determine the significant differences between a control group mean and the treatment group means in the ANOVA setting (Zar 1999). The overall mean value was used as the control group mean, since we wanted to compare each distance to seamount to the overall mean (C. W. Dunnett pers. comm.).

Additionally, we have identified those seamounts that showed significant aggregations. Firstly, for those species that showed significant associations with seamounts, we estimated their abundance in the first $10 \mathrm{~km}$ for each seamount and compared this value with the overall mean for the $10 \mathrm{~km}$ bin. These analyses were performed with a common $Z$-test on $\log (x+1)$ transformed data (Zar 1999). Finally, we estimated species abundance in relation to seamount summit depths. Mean values of abundance for each seamount depth interval were then compared with the overall mean abundance to determine whether seamount depth could be an important factor in explaining species abundances. These analyses were also performed with a common $Z$-test .

\section{RESULTS}

\section{Tuna}

Observers recorded $>4000$ tuna fishing events during the period 1998 to 2004. The most common species caught with observers onboard during this period were skipjack and bigeye tuna, with about 1500 and $962 \mathrm{t}$, respectively. The frequency distribution of the distances to seamount summit of the dataset of tuna fishing events and of a set of an equal number of randomly selected locations is shown in Fig. 2. Calculation of the $G$-statistic for the log-likelihood ratio goodness-of-fit test show significant differences $(G=2344, \mathrm{df}=25, \mathrm{p} \ll$ 0.001 ) between these 2 distributions. The results of this test allow us to assume that fishing locations were not randomly selected and thus to explore the influence of seamounts on tuna catches.

Tuna catches $\mathrm{km}^{-2} \mathrm{yr}^{-1}$ (Fig. 3) were significantly different at different distances from seamount summits (ANOVA $\mathrm{p} \ll 0.001$ for skipjack Katsuwonus pelamis and bigeye tuna Thunnus obesus). For skipjack (Fig. $3 \mathrm{a})$, catches occurring within $30 \mathrm{~km}$ from seamount summits were significantly higher than the overall mean (Dunnett tests for $10 \mathrm{~km}, 20$ and $30 \mathrm{~km}, \mathrm{p}<0.01$ ), with catches in all other areas being smaller. Bigeye tuna catches $\mathrm{km}^{-2} \mathrm{yr}^{-1}$ (Fig. 3b) were significant higher within $20 \mathrm{~km}$ of the summits (Dunnett tests for 10 and $20 \mathrm{~km}, \mathrm{p}<0.01$; for $30 \mathrm{~km}, \mathrm{p}>0.05$ ).

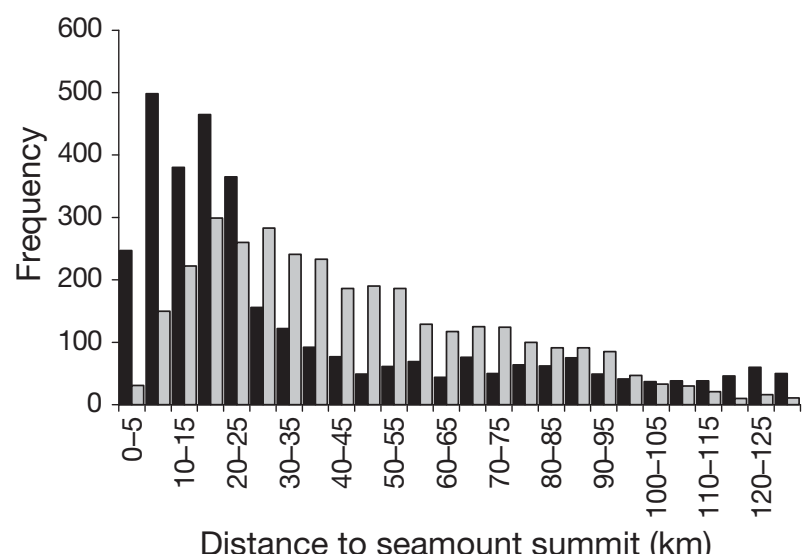

Fig. 2. Frequency distribution of the distances to seamount summit of the dataset of tuna fishing events and of a set of an equal number of randomly selected locations. Black bars: observed data; light grey bars: randomly selected locations 


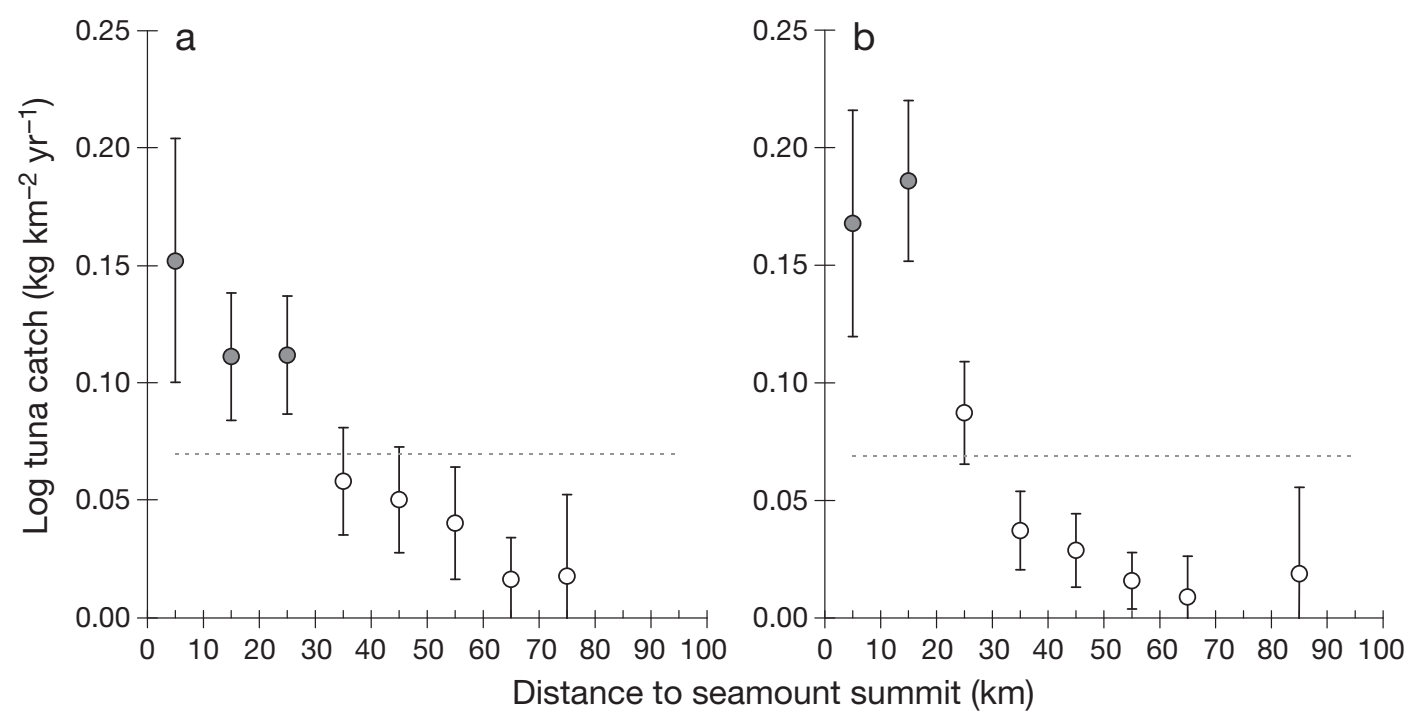

Fig. 3. Katsuwonus pelamis and Thunnus obesus. Tuna catch $( \pm 95 \%$ confidence limits, CL) in relation to the distance to the nearest seamount summit in the Azores. (a) Skipjack, (b) bigeye tuna. Bin size is $10 \mathrm{~km}$. Grey circles are significantly higher (Dunnett test) than the overall mean (light grey dashed line)

\section{Other visitors}

A total of 3910 sightings of marine mammals were recorded from 1998 to 2004. The most commonly sighted species were common dolphin Delphinus delphis, spotted dolphin Stenella frontalis, bottlenose dolphin Tursiops truncatus and sperm whale Physeter macrocephalus. Common dolphins were sighted at significantly higher frequencies in the vicinity of seamounts (ANOVA p $\ll 0.001$ ), whereas all other species showed no significant differences (ANOVAs bottlenose dolphin, $p=0.402$; spotted dolphin, $p=0.230$; sperm whale, $p=0.222$ ). The common dolphin (Fig. 4a) showed some association with seamounts. Highest observations $\mathrm{km}^{-2} \mathrm{~h}^{-1}$ were recorded close to seamount summits (Dunnett tests for 10 and $20 \mathrm{~km}, \mathrm{p}<0.01$; for $30 \mathrm{~km}, \mathrm{p}>0.05)$. On the other hand, bottlenose dolphins (Fig. 4b), spotted dolphins (Fig. 4c) and sperm whales (Fig. 4d) showed no association with seamounts and were not more abundant in the vicinity of these features.

From 2000 to 2004 there were 566 valid observer sighting records of loggerhead turtle Caretta caretta. The analyses of the number of loggerheads $\mathrm{km}^{-2} \mathrm{~h}^{-1}$ (Fig. 5) showed no differences with distance to seamount summits (ANOVA sea turtles, $p=0.401$ ). As for seabirds, the distance to seamount summit influenced the abundance of Cory's shearwater Calonectris diomedea borealis (ANOVA p $<<0.001$ ). The abundance of Cory's shearwater (Fig. 6a) was higher in the first $20 \mathrm{~km}$ from the seamount summit. However, only the second distance bin $(10$ to $20 \mathrm{~km}$ ) was significantly higher than the overall mean (Dunnett tests for $10 \mathrm{~km}, \mathrm{p}>0.05$; for
$20 \mathrm{~km}, \mathrm{p}<0.01$; for $30 \mathrm{~km}, \mathrm{p}>0.05)$. Terns Sterna hirundo and $S$. dougalli (Fig. 6b) and yellow-legged gull Larus cachinnans atlantis (Fig. 6c) abundances where not different at different distances from seamounts (ANOVA yellow-legged gull, $\mathrm{p}=0.285$; terns, $\mathrm{p}=0.998$ ).

\section{Seamount characteristics}

For those species with a significant association with seamounts, catches and sightings above seamounts of various depths are shown in Fig. 7. Skipjack and bigeye tuna showed significantly higher catches on seamounts shallower than $400 \mathrm{~m}$ depth (Fig. 7a,b), whereas common dolphin (Fig. 7c) and Cory's shearwater (Fig. 7d) showed significantly higher sightings on seamounts with depths between 200 and $400 \mathrm{~m}$. In all cases, seamounts with deep summits had relatively low catches and sightings.

We have also identified the seamounts that produced a significant effect on species aggregation. For skipjack, 'Formigas and Dollabarat' (Seamount 13, p = 0.012), 'Princesa Alice' (Seamount 50, p =0.014), 'D. João de Castro' (Seamount 25, p = 0.026), 'Açores' (Seamount 51, p = 0.030), 'Pico Leste' of the 'Princesa Alice' (Seamount 23, p = 0.028) and 'Alcatraz' (Seamount 26, p =0.044) showed significantly higher catches than the overall mean. For bigeye, only 'Açores' (Seamount 51, p = 0.004), 'Princesa Alice' (Seamount 50, p = 0.009) and 'D. João de Castro' (Seamount 25, p = 0.041) showed significantly higher catches than the overall mean. Common dolphin showed higher abundances on top of 'Açores' (Sea- 


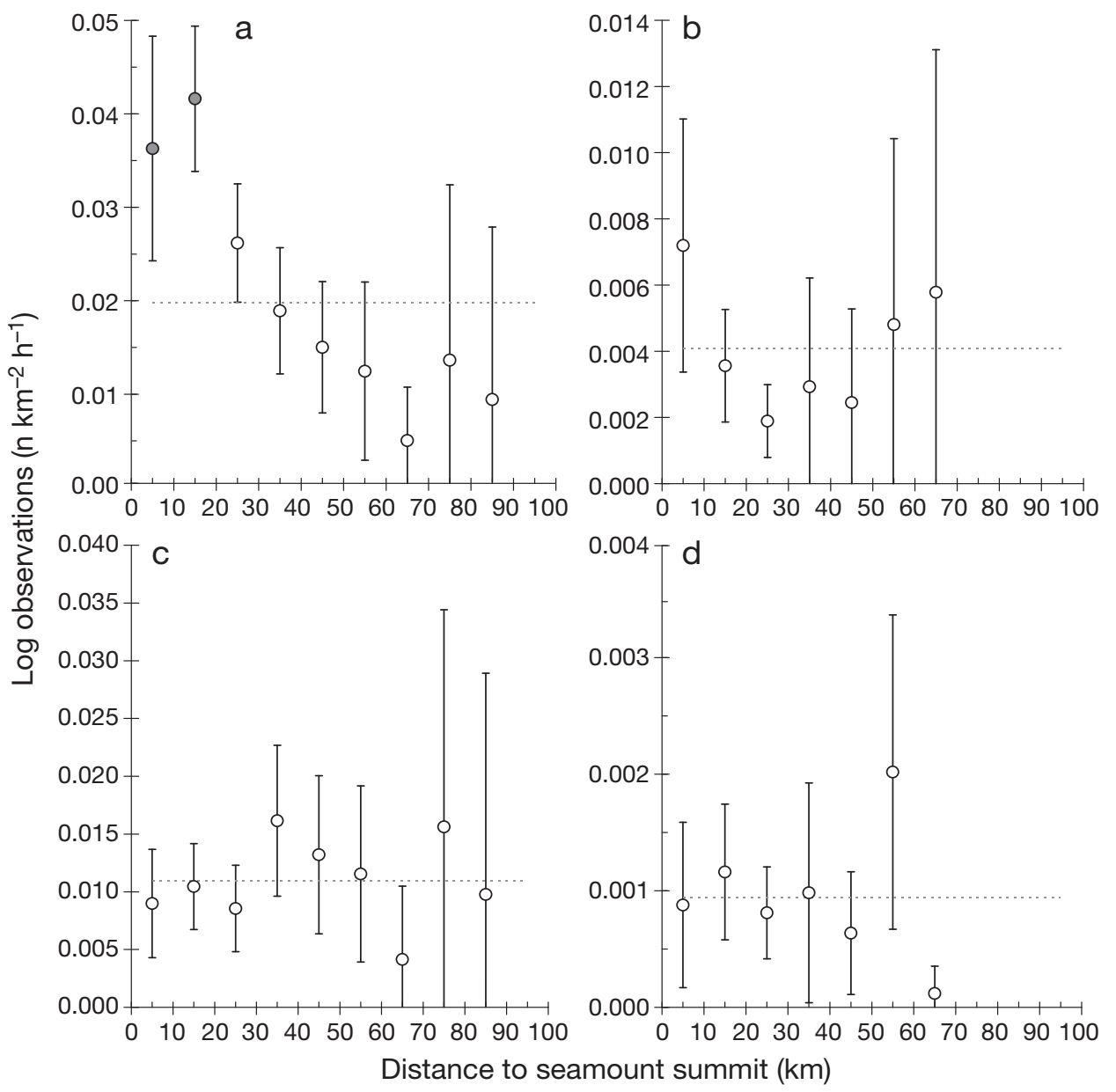

Fig. 4. Delphinus delphis, Tursiops truncatus, Stenella frontalis and Physeter macrocephalus. Marine mammals sightings ( $\pm 95 \%$ $\mathrm{CL}$ ) in relation to the distance to the nearest seamount summit in the Azores. (a) Common dolphin, (b) bottlenose dolphins, (c) spotted dolphin and (d) sperm whale. Bin size is $10 \mathrm{~km}$. Grey circles are significantly higher (Dunnett test) than the overall mean (grey dashed line)

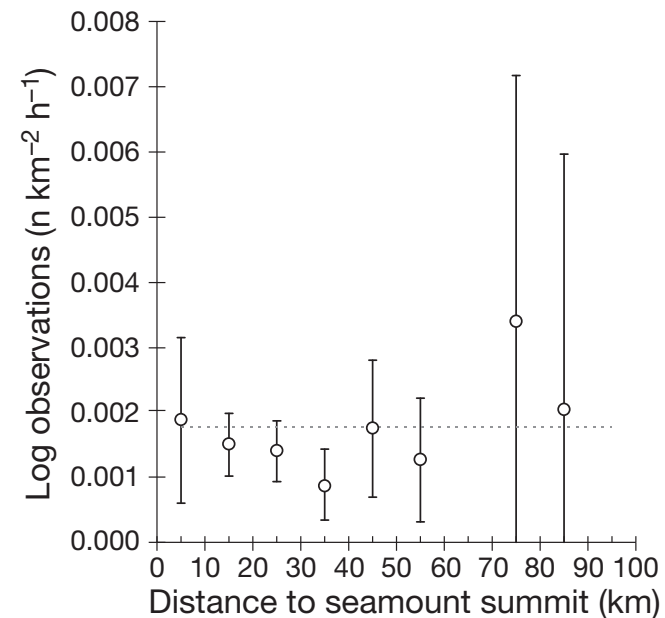

Fig. 5. Caretta caretta. Loggerhead turtles sightings ( $\pm 95 \% \mathrm{CL})$ in relation to the distance to the nearest seamount summit in the Azores. Bin size is $10 \mathrm{~km}$. The overall mean is also shown (grey dashed line) mount 51, $\mathrm{p}=0.002$ ), 'Princesa Alice' (Seamount 50, $\mathrm{p}=0.012$ ) and 'Agulhas do Sul do Gigante' (Seamount 36, p = 0.042), whereas Cory's shearwater showed higher sightings on top of 'Princesa Alice' (Seamount 50, p = 0.003) and 'Açores' (Seamount 51, $\mathrm{p}=0.006)$.

\section{DISCUSSION}

This study has demonstrated that some marine predators are associated with seamounts with quite shallow summits. This was the case of tuna species skipjack Katsuwonus pelamis and bigeye Thunnus obesus, common dolphin Delphinus delphis and Cory's shearwater Calonectris diomedea borealis. These species were significantly more abundant in the vicinity of some seamount summits than in other locations further away from these features. 


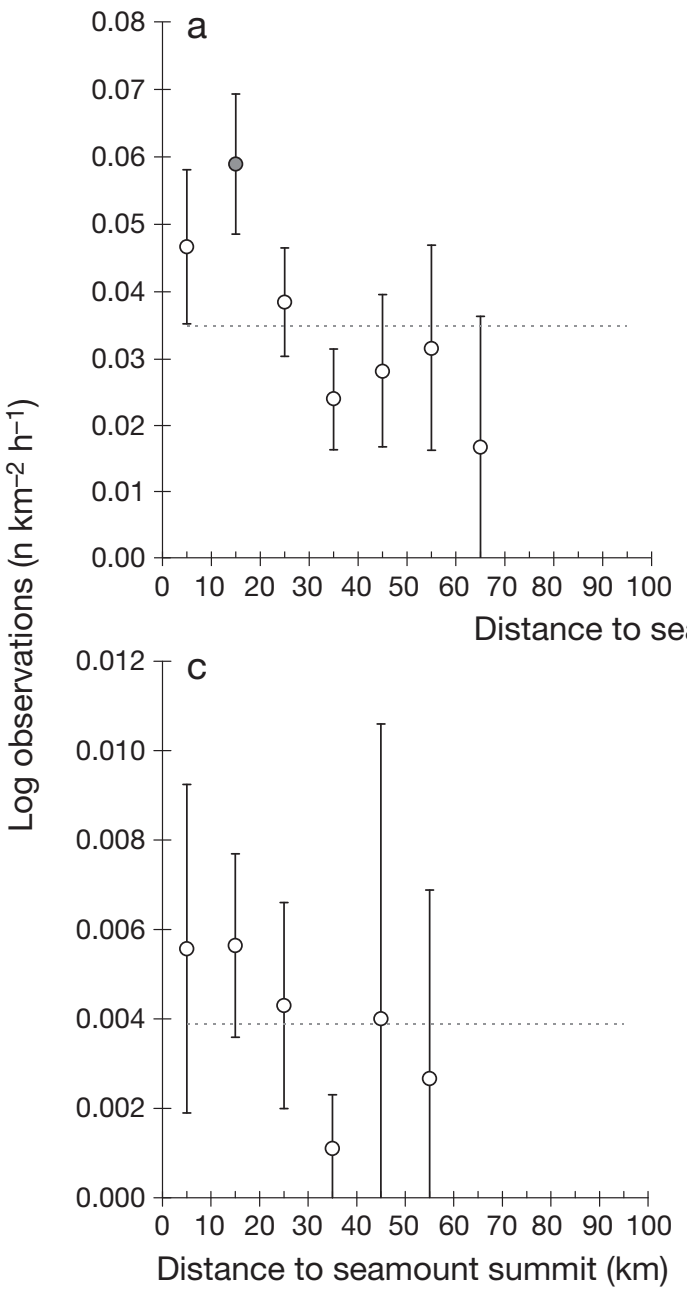

Seamounts probably localize pelagic prey and thus attract some species of pelagic fish, seabirds and marine mammals. That is, some seamounts in the Azores may act as feeding stations for some of these visitors. Tuna species such as skipjack and bigeye have previously been known to occur on seamounts, but this study is the first to quantitatively demonstrate the spatial characteristics of these associations. Common dolphins are known to feed mostly on small pelagic fish and squids (Silva 1999) and may, therefore, take advantage of the localized abundance of these prey items on seamounts. Common dolphin species are also known to be comparatively more characteristic of offshore habitats than the bottlenose Tursiops truncatus or spotted dolphins Stenella frontalis (Lopez et al. 2004). Thus, common dolphins may use remote seamounts as feeding areas. As for seabirds, our results support the findings of Monteiro et al. (1996), who inferred from stomach contents data that Cory's shearwaters feed often in association with seamounts.

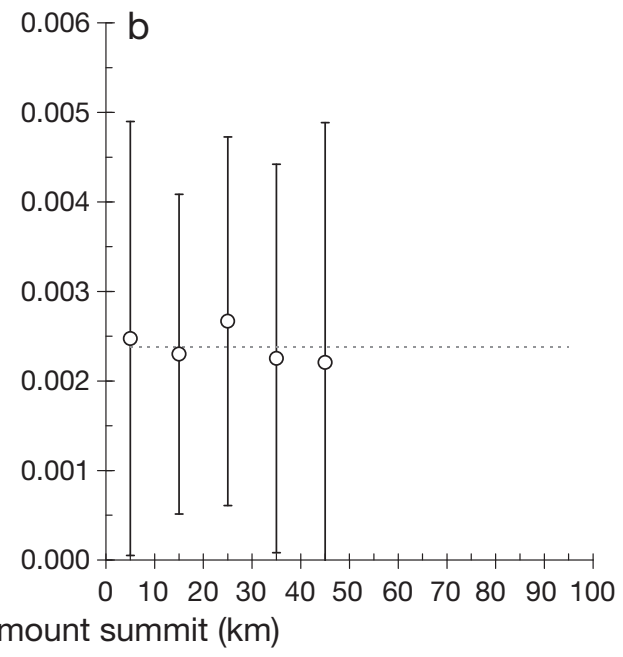

Fig. 6. Calonectris diomedea borealis, Sterna hirundo, S. dougalli and Larus cachinnans atlantis. Seabird sightings $( \pm 95 \% \mathrm{CL})$ in relation to the distance to the nearest seamount summit in the Azores. (a) Cory's shearwater, (b) terns, and (c) yellow-legged gull. Bin size is $10 \mathrm{~km}$. Grey circle is significantly higher (Dunnett test) than the overall mean (grey dashed line)

Not all seamounts, however, seemed to be equally important for these associations. For all species only seamounts shallower than $400 \mathrm{~m}$ depth showed significant aggregation effects. The important seamounts for these visitors in the studied fraction of the Azores EEZ are 'Princesa Alice' (Seamount 50) and 'Açores' (Seamount 51) for all 4 species, also 'D. João de Castro' (Seamount 25) just for the 2 tuna species, 'Formigas and Dollabarat' (Seamount 13), 'Pico Leste' of the 'Princesa Alice' (Seamount 23) and 'Alcatraz' (Seamount 26) only for skipjack, and 'Agulhas do Sul do Gigante' (Seamount 36) only for common dolphin. These seamounts should be considered hotspots of marine life in the Azores, and a special effort should be made in order to ensure a sustainable management of these habitats. These seamounts are also known to be heavily exploited by local fishermen, with the exception of the seamount 'Formigas and Dollabarat', which is a marine reserve. Reconciling fisheries with conservation on these seamounts should be a priority for the local management authorities. Management strategies 


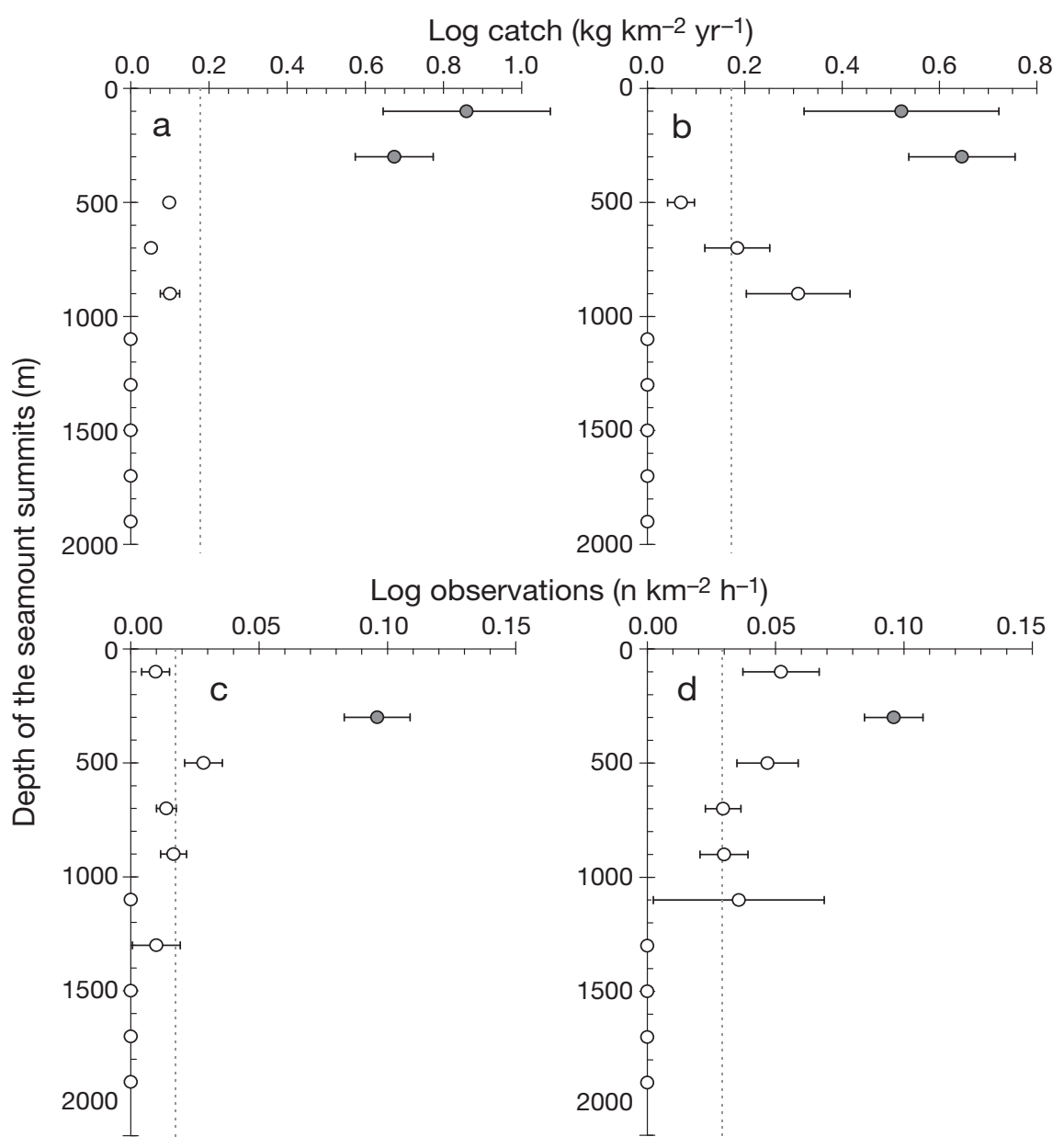

Fig. 7. Katsuwonus pelamis, Thunnus obesus, Delphinus delphins and Calonectris diomedca borealis. Catches and sightings $( \pm 95 \%$ CL) above seamounts of various depths for those species with a significant association with seamounts. (a) Skipjack, (b) bigeye tuna, (c) common dolphin and (d) Cory's shearwater. Bin size is $10 \mathrm{~km}$. Grey circles are significantly higher (Z-test) than the overall mean (grey dashed line)

should recognize that the area of influence of the seamounts seemed to be about 20 to $30 \mathrm{~km}$ from the peak.

Our methodology failed to demonstrate a seamount association for bottlenose dolphins Tursiops truncatus, spotted dolphin Stenella frontalis, sperm whale Physeter macrocephalus, terns Sterna hirundo and $S$. dougalli, yellow-legged gull Larus cachinnans atlantis and loggerhead sea turtles Caretta caretta. Whereas, for some species, the lack of association with seamounts seems reasonable, for others, it is more difficult to explain. The lack of association of sperm whales with seamount summits is not surprising, since these animals prey mostly in deep waters on large squid (Clarke et al. 1993) by echo-locating deep prey patches in the mesopelagic environment (Watwood et al. 2006). In any case, it must be stressed that some studies revealed sperm whale associations with specific types of bottom topography (Gregr \& Trites 2001, Waring et al. 2001). The lack of association with seamounts for bottlenose dolphins could be related to the lack of data points for distance bins far from the summit as expressed by the large error bars around the means. We cannot exclude, however, the fact that this species has different forms, which differ in prey preferences (e.g. Walker et al. 1999) and, thus, may be associated with different types of habitat. Although genetic studies have shown that bottlenose dolphins in the Azores are more related to the NW Atlantic pelagic type than with coastal types, both resident and non-transient forms have been identified (Quérouil et al. 2007 and references therein). The lack of association found in the present study may reflect the predominance in the Azores of a form that is more associated with coastal than with offshore habitats, as has been found in other areas (Jefferson \& Schiro 1997, Lopez et al. 2004); this would agree with the results of Silva et al. (2003), who found that that bottlenose dolphins in the Azores are primarily encountered within $9 \mathrm{~km}$ from the shore. 
Yellow-legged gulls feed opportunistically on several prey, such as fish, barnacles and even rats (Monteiro et al. 1996); therefore, there is no reason to expect an association of this species with seamounts. However, the lack of association with seamounts of terns was somewhat unexpected, because in the Azores these species feed mainly on small pelagic and mesopelagic fish (Monteiro et al. 1996), which are expected to have higher abundances close to seamounts. It is possible that during the breeding season, when this species is mostly seen in the Azores, terns stay close to their nest, thus not travelling to offshore seamounts.

Loggerhead sea turtles are widely distributed in the North Atlantic during the oceanic phase when they feed mainly on jellyfish (Bolten 2003). The lack of association of loggerhead with seamounts may be simply explained by the fact that there is no reason to believe that jellyfish abundance should be higher on top of seamounts then elsewhere. This species may be significantly associated with large oceanographic anomalies, such as fronts and currents (Polovina et al. 2004, 2006), where food for loggerheads may be more abundant. Etnoyer et al. (2006) also found topographic features like the shelf break and seamounts to be unimportant factors in explaining the distribution of these turtles. Loggerheads, however, may use the magnetic signatures of seamounts for large-scale navigation proposes (Lohmann \& Lohmann 2003).

The presence of large concentrations of forage fish during the summer in the Azores results in mixedspecies feeding aggregations of predators (Clua \& Grosvalet 2001, Silva et al. 2002). Tuna may force prey to the surface, where they are further concentrated by common dolphins, resulting in the formation of a compact 'ball' of forage fish close to the surface. Therefore, we cannot exclude the hypothesis that the seamount association of the shearwaters and dolphins can be related to the presence of tuna schools in addition to the presence of seamounts.

Acknowledgements. T.M. acknowledges support from the 'Fundação para a Ciência e Tecnologia' (Portugal, SFRH/ BD/4473/2001 and SFRH/BPD/27007/2006), POCI 2010 and the European Social Fund. We are grateful to H. Dowlatabadi, P. D. M. Macdonald and C. W. Dunnett for their committed assistance. We thank the 3 anonymous referees for their comments, which greatly improved the manuscript. IMARDOP/UAÇ (Research Unit 531 and part of the Associated Laboratory 9) is funded annually by FCT and DRCT.

\section{LITERATURE CITED}

Adam MS, Sibert J, Itano D, Holland K (2003) Dynamics of bigeye (Thunnus obesus) and yellowfin (T. albacares) tuna in Hawaii's pelagic fisheries: analysis of tagging data with a bulk transfer model incorporating size-specific attrition. Fish Bull 101:215-228
Balcomb KC III (1989) Baird's beaked whale Berardius bairdii Stejneger, 1883 and Arnoux's beaked whale Berardius arnuxii Duvernoy, 1851. In: Ridgway SH, Harrison R (eds) Handbook of marine mammals, Vol 4. Academic Press, London, p 261-288

Bjorndal KA, Bolten AB, Martins HR (2000) Somatic growth model of juvenile loggerhead sea turtles Caretta caretta: duration of pelagic stage. Mar Ecol Prog Ser 202:265-272

Boehlert GW (1988) Current-topography interactions at midocean seamounts and the impact on pelagic ecosystems. GeoJournal 16:45-52

Boehlert GW, Sasaki T (1988) Pelagic biogeography of the armorhead, Pseudopentaceros wheeleri, and recruitment to isolated seamounts in the North Pacific Ocean. Fish Bull 86:453-466

Bolten AB (2003) Active swimmers-passive drifters: the oceanic juvenile stage of loggerheads in the Atlantic system. In. Bolten AB, Witherington BE (eds) Loggerhead sea turtles. Smithsonian Institution Press, Washington, DC, p 63-78

Cañadas A, Sagarminaga R, García-Tiscar S (2002) Cetacean distribution related with depth and slope in the Mediterranean waters off southern Spain. Deep-Sea Res I 49: 2053-2073

Clarke MR, Martins HR, Pascoe P (1993) The diet of sperm whales (Physeter macrocephalus Linnaeus, 1758) off the Azores. Philos Trans R Soc Lond B 339(1287):67-82

Clua E, Grosvalet F (2001) Mixed-species feeding aggregation of dolphins, large tunas and seabirds in the Azores. Aquat Living Resour 14:11-18

Doty MS, Oguri M (1956) The island mass effect. J Cons Int Explor Mer 22:33-37

Etnoyer P, Canny D, Mate BR, Morgan LE, Ortega-Ortiz JG, Nichols WJ (2006) Sea-surface temperature gradients across blue whale and sea turtle foraging trajectories off the Baja California Peninsula, Mexico. Deep-Sea Res II 53(3-4):340-358

Fonteneau A (1991) Monts sous-marins et thons dans l'Atlantique tropical est. Aquat Living Resour 4:13-25

Fréon P, Dagorn L (2000) Review of fish associative behaviour: toward a generalisation of the meeting point hypothesis. Rev Fish Biol Fish 10(2):183-207

Genin A, Dayton PK, Lonsdale PF, Spiess FN (1986) Corals on seamount peaks provide evidence of current acceleration over deep-sea topography. Nature 322:59-61

Gonçalves JM, Galhardo L, Brum J (1992) Marine mammals stranded in the Azores during 1990-91. Arquipel Cienc Biol Mar 10:113-118

Gonçalves JM, Barreiros JP, Azevedo JN, Norberto R (1996) Cetaceans stranded in the Azores during 1992-1996. Life Mar Sci 14A:57-65

Gregr EJ, Trites AW (2001) Predictions of critical habitat for five whale species in the waters of coastal British Columbia. Can J Fish Aquat Sci 58:1265-1285

Haney JC, Haury LR, Mullineaux LS, Fey CL (1995) Sea-bird aggregation at a deep North Pacific seamount. Mar Biol 123:1-9

Hastie GD, Wilson B, Wilson LJ, Parsons KM, Thompson PM (2004) Functional mechanisms underlying cetacean distribution patterns: hotspots for bottlenose dolphins are linked to foraging. Mar Biol 144:397-403

Hazin FHV, Zagaglia JR, Broadhurst MK, Travassos PEP, Bezerra TRQ (1998) Review of a small-scale pelagic longline fishery off northeastern Brazil. Mar Fish Rev 60(3):1-8

Holland KN, Kleiber P, Kajiura SM (1999) Different residence times of yellowfin tuna, Thunnus albacares, and bigeye tuna, T. obesus, found in mixed aggregations over a seamount. Fish Bull 97:392-395 
Hooker SK, Whitehead H, Gowans S, Baird RW (2002) Fluctuations in distribution and patterns of individual range use of northern bottlenose whales. Mar Ecol Prog Ser 225:287-297

Itano DG, Holland KN (2000) Movement and vulnerability of bigeye (Thunnus obesus) and yellowfin tuna (Thunnus albacares) in relation to FADs and natural aggregation points. Aquat Living Resour 13(4):213-223

Jefferson TA, Schiro AJ (1997) Distribution of cetaceans in the offshore Gulf of Mexico. Mamm Rev 27(1):27-50

Klimley AP, Butler SB, Nelson DR, Stull AT (1988) Diel movements of scalloped hammerhead sharks, Sphyrna lewini Griffith and Smith, to and from a seamount in the Gulf of California (Mexico). J Fish Biol 33(5):751-762

Klimley AP, Jorgensen SJ, Muhlia-Melo A, Beavers SC (2003) The occurrence of yellowfin tuna (Thunnus albacares) at Espiritu Santo Seamount in the Gulf of California. Fish Bull 101:684-692

Klimley AP, Richard JE, Jorgensen SJ (2005) The home of blue water fish. Am Sci 93:42-49

Koslow JA (1997) Seamounts and the ecology of deep-sea fisheries. Am Sci 85: 168-176

Lohmann KJ, Lohmann CMF (2003) Orientation mechanisms of hatchling loggerheads. In: Bolten $\mathrm{AB}$, Witherington $\mathrm{BE}$ (eds) Loggerhead sea turtles. Smithsonian Institution Press, Washington, DC, p 44-62

Lopez A, Pierce GJ, Valeiras X, Santos MB, Guerra A (2004) Distribution patterns of small cetaceans in Galician waters. J Mar Biol Assoc UK 84(1):283-294

Monteiro LR, Ramos JR, Furness RW, del Nevo AJ (1996) Movements, morphology, breeding, molt diet and feeding of seabirds in the Azores. Colon Waterbirds 19:82-97

Morato T, Cheung WWL, Pitcher TJ (2006) Vulnerability of seamount fish to fishing: fuzzy analysis of life history attributes. J Fish Biol 68:209-221

Morato T, Machete M, Kitchingman A, Tempera F, and others (2008) Abundance and distribution of seamounts in the Azores. Mar Ecol Prog Ser 357:17-21

Musyl MK, Brill RW, Boggs CH, Curran DS, Kazama TK, Seki MP (2003) Vertical movements of bigeye tuna (Thunnus obesus) associated with islands, buoys, and seamounts near the main Hawaiian Islands from archival tagging data. Fish Oceanogr 12(3):152-169

Pitcher TJ, Morato T, Hart PJB, Clark MR, Haggan N, Santos RS (2007) Seamounts: ecology, fisheries and conservation. Fish and Aquatic Resources Series 12, Blackwell, Oxford

Polovina J, Balazs G, Howell E, Parker D, Seki M, Dutton P (2004) Forage and migration habitat of loggerhead (Caretta caretta) and olive ridley (Lepidochelys olivacea) sea turtles in the central North Pacific Ocean. Fish Oceanogr 13:36-51

Polovina J, Uchida I, Balazs G, Howell EA, Parker D, Dutton P (2006) The Kuroshio Extension Bifurcation Region: a pelagic hotspot for juvenile loggerhead sea turtles. DeepSea Res II 53(3-4):326-339

Quérouil S, Silva MA, Freitas L, Prieto R and others (2007) High gene flow in oceanic bottlenose dolphins (Tursiops truncatus) of the North Atlantic. Conserv Genet 8(6): 1405-1419

Santos MA, Bolten AB, Martins HR, Riewald B, Bjorndal KA (2007) Air-breathing visitors to seamounts: sea turtles. In: Morato T, Pauly D (eds) Seamounts: biodiversity and fisheries. Fish Cent Res Rep 12(5):239-244
Santos MA, Bolton AB, Martins HR, Riewald B, Bjorndal KA (2007) Air-breathing visitors to seamounts: sea turtles. In Pitcher TJ, Morato T, Hart PJB, Clark MR, Haggan N, Santos RS (eds) Seamounts: ecology fisheries and conservation. Fish and Aquatic Resources Series 12. Blackwell, Oxford, p 239-244

Santos RS, Hawkins SJ, Monteiro LR, Alves M, Isidro EI (1995) Marine research, resources and conservation in the Azores. Aquat Conserv 5(4):311-354

Schoenherr JL (1991) Blue whales feeding on high concentrations of euphausiids around Monterey Submarine Canyon. Can J Zool 69:583-594

Sedberry GR, Loefer JK (2001) Satellite telemetry tracking of swordfish, Xiphias gladius, off the eastern United States. Mar Biol 139:355-360

Sibert J, Holland K, Itano D (2000) Exchange rates of yellowfin and bigeye tunas and fishery interaction between Cross seamount and near-shore fads in Hawaii. Aquat Living Resour 13(4):225-232

Sibert JR, Musyl MK, Brill RW (2003) Horizontal movements of bigeye tuna (Thunnus obesus) near Hawaii determined by Kalman filter analysis of archival tagging data. Fish Oceanogr 12(3):141-151

Silva MA (1999) Diet of common dolphins, Delphinus delphis, off the Portuguese continental coast. J Mar Biol Assoc UK 79:531-540

Silva MA, Feio R, Prieto R, Gonçalves JM, Santos RS (2002) Interactions between cetaceans and the tuna fishery on the Azores. Mar Mamm Sci 18(4):893-901

Silva MA, Prieto R, Magalhães S, Cabecinhas R, Cruz A, Gonçalves JM, Santos RS (2003) Occurrence and distribution of cetaceans in the waters around the Azores (Portugal), summer and autumn 1999-2000. Aquat Mamm 29(1): $77-83$

Tseytlin VB (1985) Energetics of fish populations inhabiting seamounts. Oceanology 25:237-239

Walker JL, Potter CW, Macko SA (1999) The diets of modern and historic bottlenose dolphin populations reflected through stable isotopes. Mar Mamm Sci 15(2):335-350

Ward P, Porter JM, Elscot S (2000) Broadbill swordfish: status of established fisheries and lessons for developing fisheries. Fish Fish 1:317-336

Waring GT, Hamazaki T, Sheehan D, Wood G, Baker S (2001) Characterization of beaked whale (Ziphiidae) and sperm whale (Physeter macrocephalus) summer habitat in shelfedge and deeper waters off the northeast U.S. Mar Mamm Sci 17(4):703-717

Watwood SL, Miller PJO, Johnson M, Madsen PT, Tyack PL (2006) Deep-diving foraging behaviour of sperm whales (Physeter macrocephalus). J Anim Ecol 75(3): 814-825

Yasui M (1986) Albacore Thunnus alalunga pole-and-line fishery around the Emperor Seamounts. NOAA Tech Rep 43:37-40

Yen PPW, Sydeman WJ, Hyrenbach KD (2004) Marine bird and cetacean associations with bathymetric habitats and shallow-water topographies: implications for trophic transfer and conservation. J Mar Syst 50:79-99

Yen PPW, Sydeman WJ, Morgan KH, Whitney FA (2005) Top predator distribution and abundance across the eastern Gulf of Alaska: temporal variability and ocean habitat associations. Deep-Sea Res II 52:799-822

Zar JH (1999) Biostatistical analysis, 4th edn. Prentice Hall, Engelwood Cliffs, NJ 